\title{
Pola pertumbuhan dan faktor kondisi madidihang, Thunnus albacares (Bonnaterre, 1788) di Samudra Hindia Bagian Timur
}

[Growth pattern and condition factor of yellowfin tuna Thunnus albacares (Bonnaterre, 1788) in Eastern Indian Ocean]

\author{
Suciadi Catur Nugroho ${ }^{\bowtie}$, Irwan Jatmiko, Arief Wujdi \\ Loka Riset Perikanan Tuna, Denpasar, Bali \\ Jl. Mertasari No. 140, Sidakarya, Denpasar Selatan, Bali, 80223
}

Diterima: 3 Agustus 2017; Disetujui: 20 Februari 2018

\begin{abstract}
Abstrak
Tuna madidihang, Thunnus albacares (Bonnaterre,1788), merupakan salah satu spesies tuna ekonomis penting dan tersebar di perairan Indonesia, termasuk di WPP 572 (Samudra Hindia bagian barat Sumatera). Salah satu aspek penting yang berkaitan dengan upaya pemanfaatan berkelanjutan adalah pola pertumbuhan dan faktor kondisi. Penelitian ini bertujuan untuk mengkaji pola pertumbuhan dan faktor kondisi ikan madidihang di Samudra Hindia Bagian Timur. Jumlah ikan contoh yang diukur panjang dan bobotnya adalah 7.550 ekor yang mempunyai sebaran panjang 76-176 cm (rata-rata $129,03 \mathrm{~cm}$ ) dan modus $150 \mathrm{~cm}$. Hubungan panjang bobot ikan tersebut adalah $\mathrm{W}=4 \times 10^{-5} \mathrm{~L}^{2,842}\left(R^{2} 0,957\right)$. Secara umum pola pertumbuhan madidihang bersifat allometrik negatif yang berarti bahwa pertambahan panjang lebih cepat daripada bobotnya. Faktor kondisi relatif rata-rata madidihang adalah 0,975 dengan kecenderungan menurun seiring bertambahnya ukuran panjang. Faktor kondisi relatif tertinggi terjadi pada kelas panjang $80 \mathrm{~cm}$ sebesar 1,061 dan terendah terjadi pada kelas panjang $170 \mathrm{~cm}$ sebesar 0,918. Faktor kondisi relatif bulanan secara umum mengalami dua kali peningkatan dalam satu tahun yaitu dari bulan Februari hingga Juni dan dari Bulan Juli hingga Desember.
\end{abstract}

Kata penting: alometrik negatif, faktor kondisi relatif, pola pertumbuhan

\begin{abstract}
Yellowfin tuna, Thunnus albacares (Bonnaterre, 1788) is one of the important economically for tuna species that spread in Indonesian waters, including in WPP 572 (Indian Ocean west coast of Sumatra). One important aspect relating to sustainable utilization is the growth pattern and the condition factor. This study aims to examine growth patterns and factor conditions of yellowfin tuna in the Eastern Indian Ocean. The number of fish samples measured in length and weight is 7,550 with length range from $76-176 \mathrm{~cm}$ (average: $129.03 \mathrm{~cm}$ ) and mode at $150 \mathrm{~cm}$. The length weight relationship of the species is $\mathrm{W}=4 \times 10^{-5} \mathrm{~L}^{2.842}\left(R^{2} 0,957\right)$. In general the growth pattern of yellowfin tuna is negative allometric which means that the length increase is faster than the weight. The average relative condition factor of yellowfin tuna is 0.975 with a tendency to decrease along with the increasing of its length. The highest relative condition factor occurred at the length class of $80 \mathrm{~cm}$ with 1,061 and the lowest occurred at length $170 \mathrm{~cm}$ with 0.918 . The monthly relative condition factor generally increased twice in one year from February to June and from July to December.
\end{abstract}

Keywords: growth pattern, negative allometric, relative condition factor,

\section{Pendahuluan}

Tuna madidihang, Thunnus albacares (Bonnaterre, 1788) termasuk famili Scombridae dan merupakan kelompok ikan tuna yang tersebar di perairan tropis (Sumadhiharga 2009). Persebaran ikan madidihang di Indonesia meliputi perairan Samudra Hindia (barat Sumatera hingga selatan Jawa, Bali dan Nusa Tenggara), Selat Makasar, Laut Flores, Teluk Tomini, Laut Sulawesi, Laut Arafura, Laut Banda, perairan sekitar Maluku dan

$\triangle$ Penulis korespondensi

Alamat surel: suciadi.cn@gmail.com
Samudra pasifik (Uktolseja et al. 1991; Wudianto \& Nikijuluw 2004).

Ikan madidihang ditangkap dengan berbagai alat tangkap seperti rawai tuna, pukat cincin, pancing ulur, dan jaring insang. Produksi madidihang yang didaratkan di Pelabuhan Benoa mendominasi sebesar $50 \%$ dari total produksi 28.000 ton pada kurun waktu 2010-2014 (Jatmiko et al. 2016a). Nilai ini diikuti oleh tuna mata besar sebesar $40 \%$ dan tuna sirip biru selatan sebesar $10 \%$. Kebutuhan dan permintaan pasar terhadap tuna 
madidihang yang terus mengalami peningkatan menyebabkan intensitas penangkapan semakin meningkat dan berdampak pada penurunan ukuran stok yang tertangkap, baik dari segi ukuran panjang maupun bobot tiap individu. Status stok madidihang di Samudra Hindia dalam keaadaan baik (IOTC 2013, ISSF 2015). Menurut IOTC (2013), laju tangkap madidihang pada perikanan pukat cincin cenderung meningkat, sedangkan laju tangkap armada rawai tuna cenderung stabil. Meskipun sumber daya perikanan termasuk sumber daya yang dapat pulih, namun apabila tidak dilakukan upaya pengelolaan secara baik dan benar dikhawatirkan akan mengancam kelestarian sumber daya tersebut.

Studi tentang hubungan panjang bobot merupakan salah satu informasi penting sebagai data pendukung pengelolaan perikanan. Informasi ini dapat memprediksi berat ikan dari data panjang yang telah diketahui yang selanjutnya dapat digunakan untuk mengestimasi produksi ikan yang didaratkan (Froese 2006). Studi tentang hubungan panjang bobot dan faktor kondisi dapat digunakan untuk mendukung pendugaan stok populasi ikan (Ricker 1979) dan dapat juga digunakan untuk memahami daur hidup spesies ikan seperti aspek reproduksi dan kondisi umum suatu populasi (Pauly 1993).

Beberapa penelitian hubungan panjang bobot tuna madidihang telah dilakukan di beberapa perairan (Nishida \& Sono 2007, Zhu et al. 2010). Penelitian ini bertujuan untuk mengkaji pola pertumbuhan dan faktor kondisi ikan madidihang yang tertangkap di Samudra Hindia Barat Sumatera, sehingga dapat dilakukan tindakan pengelolaan untuk keberlanjutan usaha penangkapannya.

\section{Bahan dan metode}

Pengumpulan data dilakukan dengan mengukur panjang cagak dan menimbang bobot madidi- hang di Pelabuhan Perikanan Samudra (PPS) Bungus, Kota Padang, Sumatera Barat dari bulan Januari hingga Desember 2015. Madidihang tersebut merupakan hasil tangkapan armada rawai tuna yang beroperasi di Samudra Hindia bagian timur (barat Sumatera) (Gambar 1) yang didaratkan di PPS Bungus.

Pengukuran panjang cagak setiap individu dilakukan dengan menggunakan kaliper besar (spesifikasi: panjang sekitar 2 meter dengan ketelitian $1 \mathrm{~cm}$ ), sedangkan bobot ditimbang dengan timbangan manual berketelitian $1 \mathrm{~kg}$. Data yang dikumpulkan kemudian dianalisis untuk menentukan sebaran panjang dan hubungan panjang bobot..

Hubungan panjang bobot ikan dianalisis untuk menentukan pola pertumbuhan ikan setiap bulan dan secara keseluruhan selama satu tahun. Hubungan panjang bobot madidihang dianalisis dengan model pertumbuhan menurut Bal \& Rao (1984) menggunakan persamaan:

$$
\mathrm{W}=\mathrm{a} \mathrm{L^{b }}
$$

Keterangan: $\mathrm{W}=$ bobot ikan $(\mathrm{kg}), \mathrm{L}=$ panjang ikan $(\mathrm{cm})$, $\mathrm{a}=$ intercept, $\mathrm{b}=$ koefisien regresi

Untuk menentukan apakah nilai b yang diperoleh lebih besar, sama dengan atau lebih kecil dari 3 dilakukan uji-t pada selang kepercayaan 95\% (Steel \& Torrie 1993).

Analisis faktor kondisi dilakukan pada setiap kisaran panjang dan setiap bulan. Faktor kondisi dihitung dengan membandingkan bobot rata-rata ikan dengan bobot prediksi yang diperoleh dari parameter penghitungan panjang bobot secara umum. Metode penghitungan faktor kondisi relatif menggunakan rumus King (2007):

$$
K n=\frac{W}{W^{\wedge}}
$$

Keterangan: $K_{n}=$ kondisi faktor relatif setiap individu ikan, $W=$ bobot ikan hasil observasi, $W^{\wedge}=$ bobot ikan hasil estimasi $\left(\mathrm{W}^{\wedge}=\mathrm{aL}^{\mathrm{b}}\right)$

\section{Pola hubungan panjang bobot dan} perkembangan faktor kondisi ikan disajikan setiap bulan selama penelitian. 


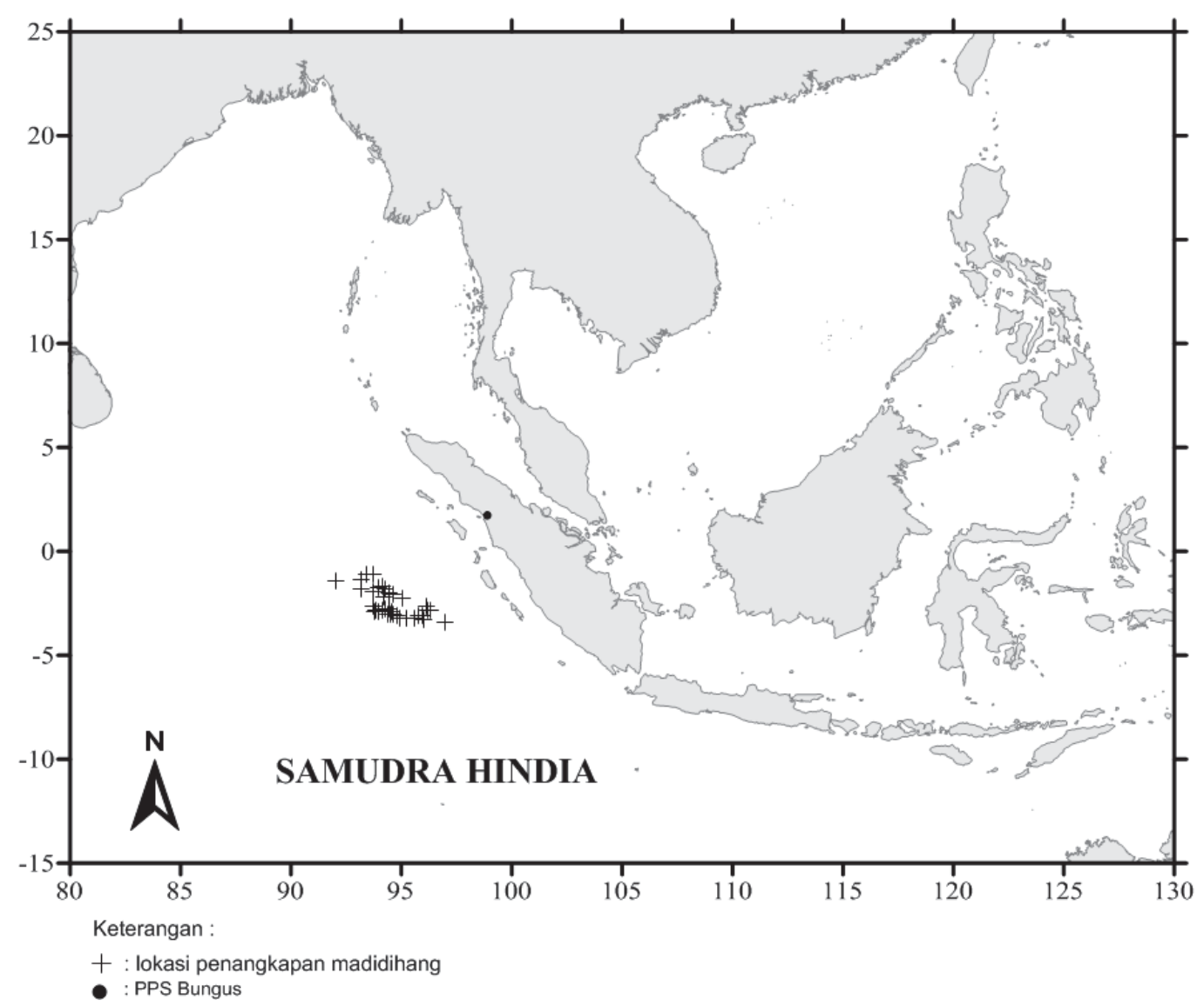

Gambar 1. Lokasi penangkapan madidihang yang didaratkan di PPS Bungus

\section{Hasil}

Tercatat sebanyak 7.550 madidihang diukur panjang dan bobotnya. Sebaran panjang madidihang tersebut adalah $76-176 \mathrm{~cm}$ dengan rata-rata $129,03 \mathrm{~cm}$ dan modus pada batas atas kelas panjang $150 \mathrm{~cm}$ (Gambar 2). Dari ukuran panjang yang diperoleh, diketahui sebesar 87,70\% memiliki panjang lebih dari $100 \mathrm{~cm}$.

Hubungan panjang bobot madidihang adalah $\mathrm{W}=4 \times 10^{-5} \mathrm{~L}^{2,842}$ dengan koefisien determinasi $\left(R^{2}\right) 0,957$. Hal ini menunjukkan bahwa panjang cagak dapat mengestimasi bobot madidihang dengan tingkat keakuratan sebesar 95,7\% (Gambar 3). Hasil uji-t nilai $b$ menunjukkan bahwa secara umum pola pertumbuhan madidihang bersifat allometrik negatif yang berarti bahwa pertambahan panjang lebih cepat daripada bobotnya. Hanya pa- da bulan Desember pola pertumbuhannya bersifat isometrik yang berarti pertambahan panjang proporsional dengan pertambahan bobotnya (Tabel 1).

Rata-rata faktor kondisi relatif madidihang adalah 0,975 dengan kecenderungan menurun seiring bertambahnya ukuran panjang. Faktor kondisi relatif tertinggi terjadi pada batas atas kelas panjang $80 \mathrm{~cm}$ sebesar 1,061 dan terendah terjadi pada batas atas kelas panjang $170 \mathrm{~cm}$ sebesar 0,918 (Gambar 4). Faktor kondisi relatif bulanan secara umum mengalami dua kali peningkatan dalam satu tahun yaitu dari bulan Februari hingga Juni dan dari Bulan Juli hingga Desember dengan nilai tertinggi terjadi pada bulan Desember sebesar 1,010 dan terendah pada bulan Februari sebesar 0,938 (Gambar 5). 


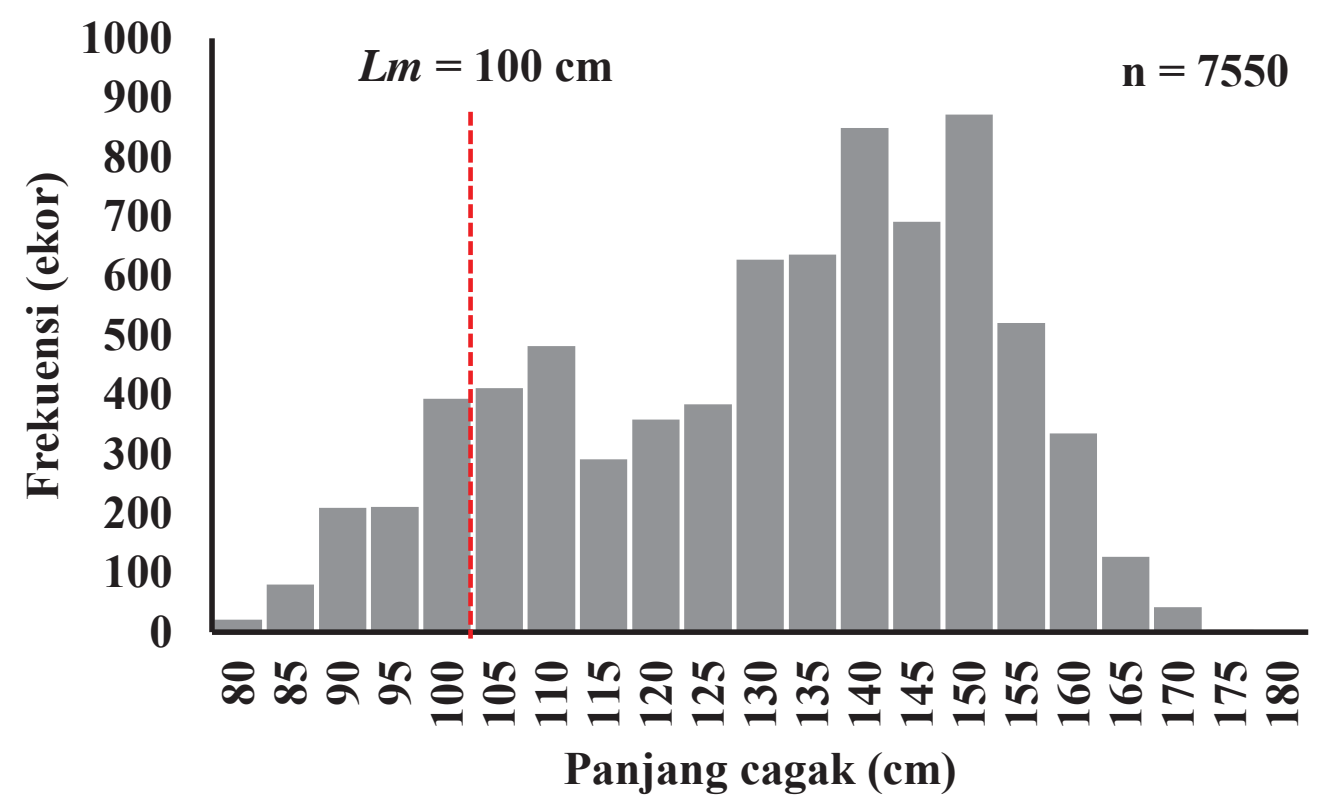

Gambar 2. Frekuensi panjang madidihang (T. albacares) yang didaratkan di PPS Bungus, Sumatera Barat pada Januari - Desember 2015. Keterangan : Lm= panjang ikan kali pertama matang gonad

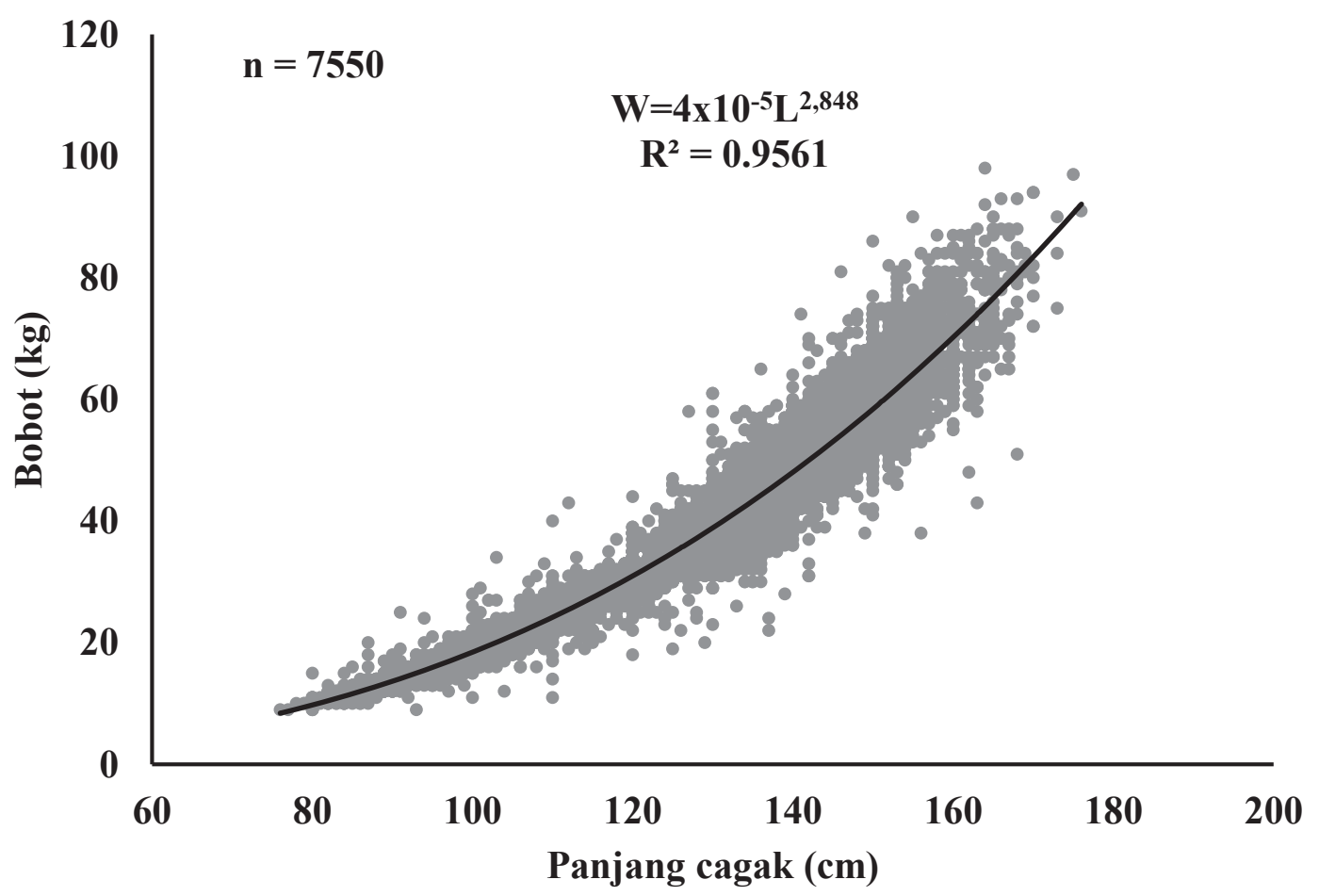

Gambar 3. Hubungan panjang bobot madidihang (T. albacares) yang didaratkan di PPS Bungus, Sumatera Barat pada bulan Januari - Desember 2015. 
Tabel 1. Parameter dan pola pertumbuhan madidihang (T. albacares) yang didaratkan di PPS Bungus, Sumatera Barat pada bulan Januari - Desember 2015

\begin{tabular}{lccccccccc}
\hline \multirow{2}{*}{ Bulan } & $N$ & \multicolumn{1}{c}{ Panjang cagak $(\mathrm{cm})$} & \multicolumn{2}{c}{ Berat $(\mathrm{kg})$} & \multicolumn{3}{c}{ Parameter } & Pola pertumbuhan \\
\cline { 3 - 8 } & & Kisaran & $\begin{array}{c}\text { Rata- } \\
\text { rata }\end{array}$ & Kisaran & $\begin{array}{c}\text { Rata- } \\
\text { rata }\end{array}$ & $a$ & $b$ & $R^{2}$ & \\
\hline Januari & 425 & $86-173$ & 134,47 & $11-90$ & 43,93 & 0,00003 & 2,903 & 0,950 & Alometrik negatif \\
Februari & 346 & $84-173$ & 134,79 & $10-84$ & 43,79 & 0,00003 & 2,876 & 0,958 & Alometrik negatif \\
Maret & 291 & $80-168$ & 134,64 & $9-77$ & 43,52 & 0,00007 & 2,708 & 0,931 & Alometrik negatif \\
April & 670 & $83-176$ & 137,26 & $12-91$ & 46,23 & 0,00008 & 2,677 & 0,919 & Alometrik negatif \\
Mei & 438 & $82-170$ & 136,31 & $11-82$ & 46,95 & 0,00006 & 2,751 & 0,918 & Alometrik negatif \\
Juni & 976 & $80-169$ & 133,84 & $10-86$ & 45,85 & 0,00004 & 2,852 & 0,951 & Alometrik negatif \\
Juli & 528 & $78-173$ & 133,52 & $10-80$ & 43,53 & 0,00006 & 2,758 & 0,964 & Alometrik negatif \\
Agustus & 509 & $76-166$ & 128,73 & $9-78$ & 39,35 & 0,00010 & 2,650 & 0,931 & Alometrik negatif \\
September & 554 & $83-169$ & 125,61 & $12-90$ & 37,50 & 0,00003 & 2,874 & 0,945 & Alometrik negatif \\
Oktober & 789 & $85-164$ & 127,92 & $11-84$ & 39,32 & 0,00003 & 2,891 & 0,944 & Alometrik negatif \\
November & 1132 & $79-170$ & 120,98 & $9-98$ & 35,09 & 0,00002 & 2,937 & 0,971 & Alometrik negatif \\
Desember & 892 & $77-175$ & 120,02 & $9-97$ & 36,10 & 0,00002 & 2,982 & 0,978 & Isometrik \\
\hline Total & 7550 & $76-176$ & 129,24 & $9-98$ & 40,98 & 0,00004 & 2,831 & 0,953 & Alometrik negatif \\
\hline
\end{tabular}

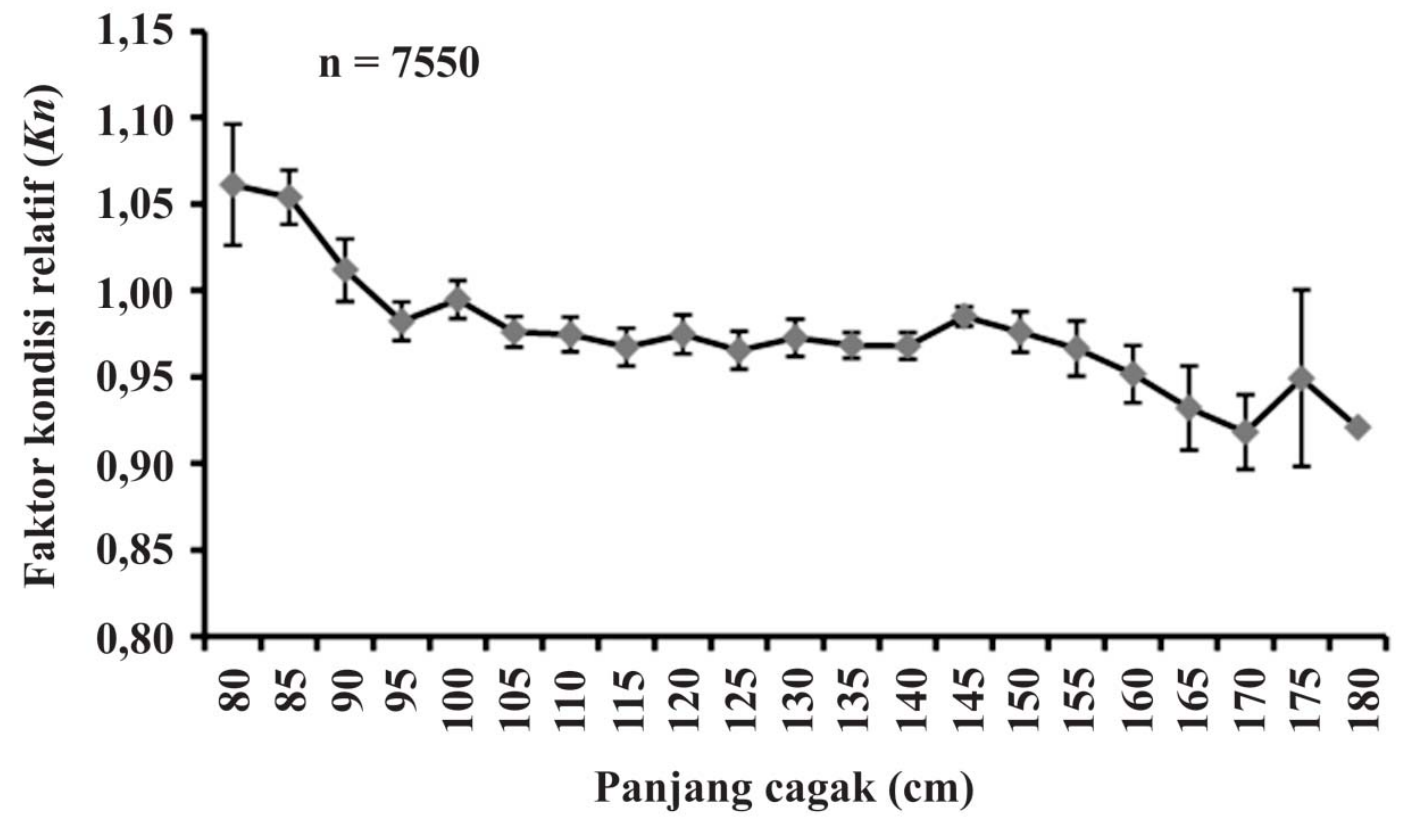

Gambar 4. Faktor kondisi relatif berdasarkan kisaran panjang madidihang (T. albacares) yang didaratkan di PPS Bungus, Sumatera Barat pada bulan Januari - Desember 2015. 


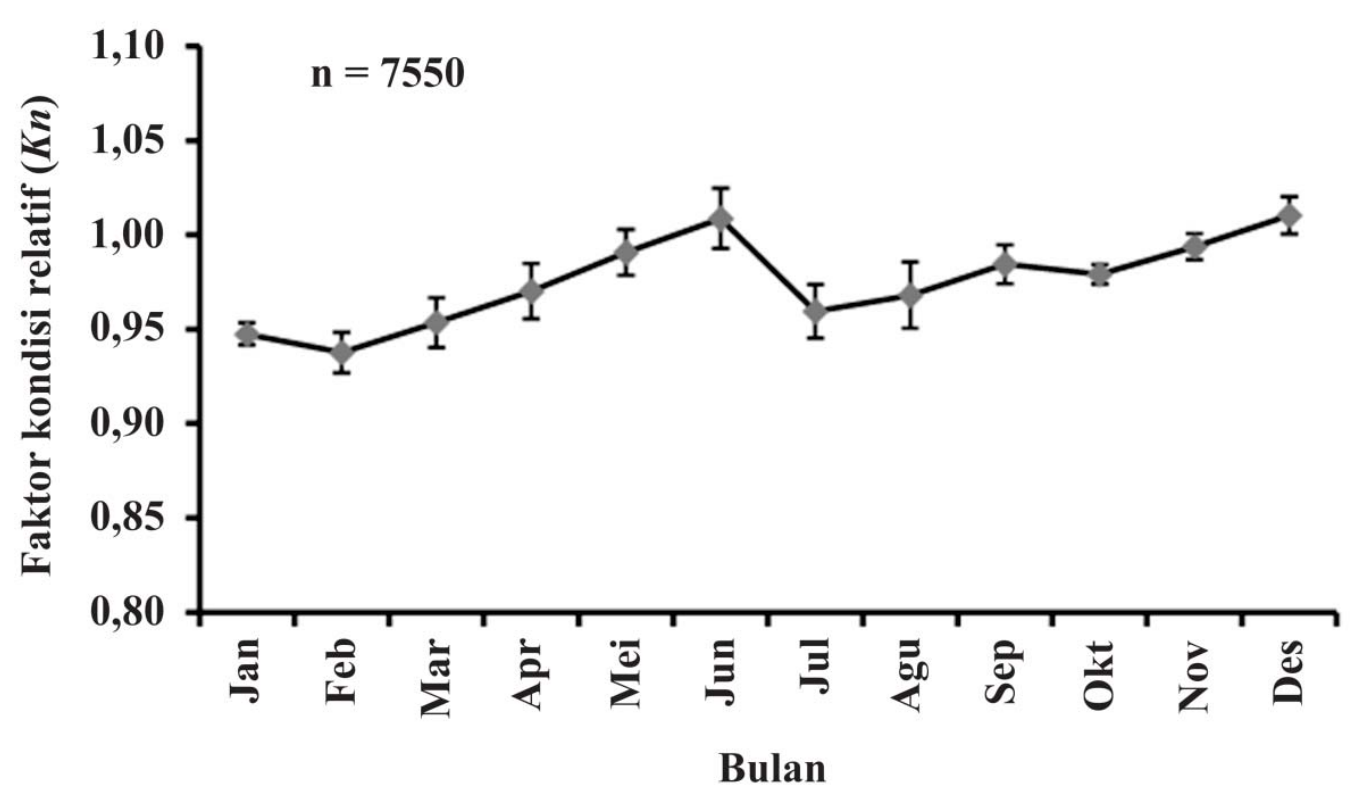

Gambar 5. Faktor kondisi relatif madidihang (T. albacares) yang didaratkan di PPS Bungus, Sumatera Barat pada bulan Januari - Desember 2015 .

\section{Pembahasan}

Ikan madidihang yang terukur pada penelitian ini berkisar pada ukuran panjang cagak $76-176$ $\mathrm{cm}$ dengan puncak modus pada ukuran $150 \mathrm{~cm}$. Secara keseluruhan, sekitar $87,70 \%$ ikan yang tertangkap memiliki panjang lebih dari $100 \mathrm{~cm}$. Nilai tersebut merupakan panjang kali pertama matang gonad madidihang (IOTC 2013; Zhu et al. 2011). Hal ini berarti $87,70 \%$ dari total hasil tangkapan ikan madidihang dapat dikatakan layak tangkap karena diduga telah melakukan pemijahan sebelum ditangkap. Berdasarkan penelitian sebelumnya diketahui bahwa di perairan Samudra Hindia bagian timur ukuran panjang cagak ikan madidihang yang tertangkap berkisar antara 30-179 cm (Wujdi et al. 2015), di perairan Samudra Hindia Selatan Bali dan Lombok ukuran panjang cagak ikan yang tertangkap berkisar 77-180 cm (Jatmiko et al. 2016b) dan 70-178 cm (Anggarini et al. 2016), di perairan Laut Banda berkisar antara 55 $215 \mathrm{~cm}$ (Damora \& Baihaqi 2013), dan perairan Majene Selat Makasar berkisar antara 25-180 cm (Kantun et al. 2014).
Pola pertumbuhan ditentukan berdasarkan nilai b yang diperoleh dari persamaan hubungan panjang bobot. Nilai $b$ menunjukkan hubungan panjang bobot yang diakibatkan oleh faktor ekologis dan biologis (Manik 2009). Faktor ekologis di antaranya adalah musim, kualitas air, suhu, $\mathrm{pH}$, salinitas, posisi geografis, dan teknik sampling (Jenning et al. 2001). Faktor biologis meliputi perkembangan gonad, kebiasaan makan, fase pertumbuhan dan jenis kelamin (Froese 2006, Tarkan et al. 2006). Kondisi lingkungan yang berubah dapat mengakibatkan kondisi ikan berubah sehingga hubungan panjang bobot akan menyimpang dari hukum kubik (Merta 1993). Sementara King (2007) menyatakan bahwa hubungan panjang bobot ikan dapat digunakan untuk menentukan kemungkinan perbedaan antara jenis yang sama pada stok yang berbeda. Kegunaan lain dari analisis hubungan panjang bobot, yaitu dapat digunakan untuk melakukan estimasi faktor kondisi atau sering disebut dengan index of plumpness, yang merupakan salah satu derivat penting dari pertumbuhan untuk membandingkan kondisi atau keadaan kese- 
hatan relatif populasi ikan atau individu tertentu (Everhart \& Youngs 1981). Analisis hubungan panjang bobot ikan madidihang selama penelitian mengikuti persamaan $\mathrm{W}=4 \times 10^{-5} \mathrm{~L}^{2.845}$ dengan pertumbuhan bersifat alometrik negatif. Pola pertumbuhan madidihang yang bersifat alometrik negatif ini serupa dengan pola pertumbuhan ikan tersebut di Samudra Hindia bagian selatan Jawa (Triharyuni \& Iskandar 2012) dan di perairan Atlantik, Samudra Pasifik bagian timur dan Samudra Hindia (Zhu et al. 2010); namun berbeda dengan pola pertumbuhan madidihang yang didaratkan di PPS Bitung yang bersifat alometrik positif (Darondo et al. 2014) ataupun dengan pertumbuhan madidihang di Samudra Hindia yang bersifat isometrik (Nishida \& Sono 2007). Pola pertumbuhan tersebut dipengaruhi oleh karakteristik perairan dalam menunjang ketersediaan makanan dan habitat yang sesuai. Effendie (2002) menyatakan bahwa makanan yang diambil akan memengaruhi pertumbuhan, kematangan tiap individu dan keberhasilan hidupnya.

Salah satu derivat penting dari pertumbuhan adalah faktor kondisi (Effendie 1997). Faktor kondisi menunjukkan keadaan baik ikan dilihat dari segi kapasitas fisik untuk sintasan dan reproduksi. Faktor kondisi ikan sangat dipengaruhi oleh pola pertumbuhan. Secara teoritis untuk mengetahui faktor kondisi digunakan faktor panjang dan bobot individu. Kondisi lingkungan yang buruk akan menyebabkan berkurangnya bobot tubuh dan bila kondisi lingkungan baik dan cukup nutrisi maka bobot badan akan bertambah.

Pengamatan terhadap contoh ikan madidihang yang didaratkan di PPS Bungus menunjukkan faktor kondisi tertinggi terdapat pada ikan-ikan berukuran kecil dengan faktor kondisi relatif ratarata adalah 0,978. Hasil penelitian ini berbeda dengan hasil penelitian yang dilakukan oleh Nurdin et al. (2012) di PPN Prigi yang diperoleh rata-rata faktor kondisi madidihang adalah 1,99 dan penelitian yang dilakukan oleh Faizah \& Aisyah (2011) di Sendang Biru sebesar 1,66. Perbedaan tersebut disebabkan ikan madidihang yang digunakan sebagai contoh pada penelitian Nurdin et al. (2012) dan Faizah \& Aisyah (2011) merupakan hasil tangkapan di sekitar rumpon sehingga hasil tangkapan didominasi oleh ikan ukuran kecil, sedangkan ikan madidihang dalam penelitian ini merupakan hasil tangkapan rawai tuna yang ukurannya relatif besar. Hasil ini diperkuat oleh pernyataan Effendie (2002) yaitu ikan yang berukuran kecil memiliki faktor kondisi yang lebih tinggi, kemudian menurun ketika ikan tersebut bertambah besar, serta peningkatan nilai faktor kondisi dapat terjadi karena pertambahan gonad yang akan mencapai puncak sebelum memijah. Faktor kondisi dapat dipengaruhi oleh ketersediaan makanan, umur, nisbah kelamin, dan tingkat kematangan gonad (Effendie 1979).

Nilai faktor kondisi bulanan terendah terjadi pada bulan Februari sebesar 0,938 dan tertinggi terjadi pada bulan Desember 1,010. Hossain (2010) menyatakan bahwa faktor kondisi merupakan indikator ketersediaan makanan di wilayah perairan dan secara umum siklus perubahan musim dapat memengaruhi perkembangan gonad. Hal ini diduga pada bulan Desember ketersediaan makanan melimpah di laut. Selain ketersediaan makanan faktor kondisi juga dipengaruhi oleh umur, jenis kelamin, dan tingkat kematang gonad. Namun dalam penelitian ini ketiga unsur tersebut belum dapat dikaji karena tidak tersedia data dan informasi yang lengkap. Oleh karena itu diperlukan penelitian lebih lanjut yang memusatkan perhatian pada faktor-faktor tersebut.

\section{Simpulan}

Pola pertumbuhan madidihang bersifat allometrik negatif yang berarti pertambahan pan- 
jang lebih cepat daripada pertambahan bobotnya. Secara umum, faktor kondisi relatif madidihang rata-rata adalah 0,978 dan cenderung mengalami peningkatan selama dua kali dalam satu tahun.

\section{Persantunan}

Penelitian ini dibiayai dari DIPA kegiatan riset Loka Penelitian Perikanan Tuna (LP2T) pada tahun 2015. Peneliti mengucapkan terima kasih kepada saudara Eka Siswanto sebagai enumerator di PPS Bungus yang telah membantu dalam proses pengumpulan data penelitian ini.

\section{Daftar Pustaka}

Anggarini KM, Saputra SW, Ghofar A, Setyadji B. 2016. Hasil tangkapan ikan madidihang (Thunnus albacares) di Samudra Hindia berdasarkan hasil tangkapan yang didaratkan di Pelabuhan Benoa, Bali. Journal of Management of Aquatic Resources, 5(4): 406-411

Bal DV, Rao KV. 1984. Marine Fisheries. Tata Mc.Graw-Hill Publishing Company Limited, New Delhi. 457 p.

Damora A, Baihaqi. 2013. Struktur ukuran ikan dan parameter populasi madidihang (Thunnus albacares) di perairan Laut Banda. Bawal, 5 (1) : 59-65

Darondo FA, Manoppo L, Luasunaung A. 2014. Komposisi tangkapan tuna hand line di Pelabuhan Perikanan Samudra Bitung, Sulawesi Utara. Jurnal Ilmu dan Teknologi Perikanan Tangkap 1(6): 227-232

Effendie IM. 1979. Metoda Biologi Perikanan. Yayasan Dewi Sri. Bogor. 112 hlm.

Effendie IM. 2002. Biologi Perikanan. Yayasan Pustaka Nusatama. Yogyakarta. $163 \mathrm{hlm}$.

Everhart WH, Youngs WD. 1981. Principle of Fishery Science. Second Edition. Comstock Publising Associates, a Division of Cornell University Press. Ithaca and London. 345 p.

Faizah R \& Aisyah. 2011. Komposisi jenis dan distribusi ukuran ikan pelagis besar hasil tangkapan pancing ulur di Sendang Biru, Jawa Timur. Bawal, 3(6): 377-385

Froese R. 2006. Cube law, condition faktor and weight-length relationships: history, meta- analysis and recommendations. Journal of Applied Ichthyology, 22(4): 241-253

Hossain Y. 2010. Length-weight, length-length relationship and condition factors of three schibid catfish from the Padma River, Northwestern Bangladesh. Asian Fisheries Science, 23 (3): 329-339

Indian Ocean Tuna Commission (IOTC). 2013. Report of the Fifteenth Session of the IOTC Working Party on Tropical Tunas. San Sebastian, Spain, 23-28 October 2013. 93 p.

International Seafood Sustainability Foundation (ISSF). 2015. ISSF Tuna Stock Status Update, 2015: Status of the world fisheries for tuna. ISSF Technical Report 2015-03A. International Seafood Sustainability Foundation, Washington, D.C., USA.

Jatmiko I, Setyadji B, Novianto D. 2016a. Produksi perikanan tuna hasil tangkapan rawai tuna yang berbasis di Pelabuhan Benoa, Bali. Jurnal Penelitian Perikanan Indonesia. 22(1): 25-32.

Jatmiko I, Hartaty H, Nugraha B. 2016b. Estimation of yellowfin tuna production in Benoa Port with weight-weight, length-weight relationships and condition factor approaches. Indonesian Fisheries Research Journal.22 (2): 77-84

Jennings S, Kaiser MJ, Reynolds JD. 2001. Marine Fishery Ecology. Blackwell Sciences, Oxford. $417 \mathrm{p}$.

Kantun W, Mallawa A, Rapi NL. 2014. Struktur ukuran dan jumlah tangkapan tuna madidihang (Thunnus albacares) menurut waktu penangkapan dan kedalaman di perairan Majene Selat Makasar. Jurnal Saintek Perikanan. 9 (2) : 39-48

King M. 2007. Fisheries Biology, Assessment and Management. Second edition. Blackwell Sciencetific Publication. Oxford. 381 p.

Manik N. 2009. Hubungan panjang-berat dan faktor kondisi ikan layang (Decapterus russelli) dari perairan sekitar Teluk Likupang Sulawesi Utara. Oseanologi dan Limnologi di Indonesia 35(1) : $65-74$.

Merta, IGS. 1993. Hubungan panjang berat dan faktor kondisi ikan lemuru, Sardinella lemuru Bleeker, 1853 dari perairan Selat Bali. Jurnal Penelitian Perikanan Laut, 73(1) : 35-44

Nishida, T. \& H. Sono. 2007. Stock Assessment of Yellowfin Tuna (Thunnus albacares) in the 
Indian Ocean by the Age Structured Production Model (ASPM) Analysis. Submitted to the IOTC $9^{\text {th }}$ WPTT Meeting, July 16-20. Victoria, 1(17): 3-4.

Nurdin E, Taurusman AA, Yusfiandayani R. 2012. Struktur ukuran, hubungan panjang bobot dan faktor kondisi ikan tuna di Perairan Prigi, Jawa Timur. Bawal, 4(2): 67-73

Pauly D. 1993. Fishbyte section editorial. Naga, the ICLARM Quarterly, 16 (2): 26-27

Ricker WE. 1979. Growth rate and models. In: Hoar WS, Randall DJ, Brett JR (Ed.). Fish Physiology. Vol. III. Bioenergetics and Growth. Academic Press. pp. 195-248

Steel RGD,Torrie H. 1993. Prinsip dan prosedur statistika suatu pendekatan biometrik. Diterjemahkan oleh Bambang Sumantri. Edisi kedua. PT. Gramedia Pustaka Utama. Jakarta. 772 p.

Sumadhiharga OK. 2009. Ikan Tuna. Pusat Penelitian Oseanografi. Lembaga Ilmu Pengetahuan Indonesia. Jakarta.

Tarkan AS, Gaygusuz O, Acipinar P, Gursoy C, Ozulug M. 2006. Length-weight relationship of fisheries from the Marmara Region (NW-Turkey). Journal of Applied Ichthyology, 22(4): 271-283

Triharyuni S, Prisantoso BI. 2012. Komposisi jenis dan sebaran ukuran tuna hasil tangkapan longline di perairan Samudra Hindia selatan Jawa. Jurnal Saintek Perikanan, 8(1) : 5258
Uktolseja JCB, Gafa B, Bahar S. 1991. Potensi dan penyebaran sumberdaya ikan tuna dan cakalang. In: Martosubroto P, Naamin N, Malik BBA (editor). Potensi dan Penyebaran Sumberdaya Ikan Laut di Perairan Indonesia. Direktorat Jenderal Perikanan. Pusat Penelitian dan Pengembangan Perikanan. Pusat Penelitian dan Pengembangan Oseanologi. Jakarta. pp. 29-43

Wudianto, Nikijuluw VPH. 2004. Guide to Invest on Fisheries in Indonesia. Directorate of Capital and Investment System. Ministry of Marine Affair and Fisheries Republic of Indonesia. $17 \mathrm{p}$.

Wujdi A, Setyadji B, Nugraha B. 2015. Sebaran ukuran panjang dan nisbah kelamin ikan madidihang (Thunnus albacares) di Samudra Hindia bagian timur. Bawal, 7(3): 175-182

Zhu G, Xu L, Zhou Y, Song L, Dai X. 2010. Length-weight relationships for bigeye tuna (Thunnus obesus), yellowfin tuna (Thunnus albacares) and albacore (Thunnus alalunga) (Perciformes: Scombridae) in the Atlantic, Indian and Eastern Pacific Oceans. Collect. Vol. Sci. Pap. ICCAT. 65(2): 717-724

Zhu G, Dai X, Song L, Xu L. 2011. Size at sexual maturity of bigeye tuna Thunnus obesus (Perciformes: Scombridae) in the Tropical Waters: a Comparative Analysis. Turkish Journal of Fisheries and Aquatic Sciences, 11(1): 149-156 
